\title{
Cyclic AMP-Dependent Transcription Factor ATF-6 Alpha
}

National Cancer Institute

\section{Source}

National Cancer Institute. Cyclic AMP-Dependent Transcription Factor ATF-6 Alpha. NCI Thesaurus. Code C113618.

Cyclic AMP-dependent transcription factor ATF-6 alpha ( $670 \mathrm{aa}, \sim 75 \mathrm{kDa}$ ) is encoded by the human ATF6 gene. This protein plays a role in the expression of unfolded protein responsive genes. 